\title{
KARAKTERISTIK SEKTOR PERTANIAN DI PROVINSI BALI MENURUT SUBSEKTOR PENYUSUN
}

\author{
Putu OKa Surya Arsana ${ }^{1}$, Made Susilawati ${ }^{2}$, Ketut Jayanegara ${ }^{3}$ \\ 1,2,3 Jurusan Matematika FMIPA Universitas Udayana, Bukit Jimbaran-Bali \\ e-mail: ${ }^{1}$ okaconstantine@ gmail.com, ${ }^{2}$ susilawati.made@ gmail.com, \\ ${ }^{3}$ ketut_jayanegara@yahoo.com
}

\begin{abstract}
Bali instead of famous for tourism also popular at agriculture. One of them is subak. It is a culture heritage in the world. To cope with this problem the development in agriculture should be increased. The goal for this research are to know the identifiier factors of agriculture devolopment in Bali, the most dominat factors, and the variable which represent the development of agriculture in Bali. The method of analysis used for this research is factors analysis. Factor analysis is used to reduce the data or summary, for variable which is being changed to a new variable called factor and still load many information contained in a real variable. The method used in the factor analysis is principal component analysis method. Many factors are determined by eigen values. The factor rotation which used is varimax rotation. Based on the research results, got seven factors with the diversities which can be explained are $76.417 \%$. Factors dryland farming as the most dominant factor identifier with the total value of the largest eigenvalues is 4.564 or $25.356 \%$ with variables representing these factors are widely planted potatoes and pulses.
\end{abstract}

Keywords: factor Analysis, principal component analysis, eigen value, factor rotation.

\section{Pendahuluan}

Pulau Bali selain terkenal dari sektor parawisata juga terkenal pada sektor pertaniannya, contohnya sistem subak yang telah menjadi warisan budaya dunia. Selain pertanian tanah sawah, Bali juga mempunyai indikator pertanian tanah bukan sawah seperti perkebunan, tanaman ubi-ubian, dan palawija serta perikanan yang kurang mendapatkan perhatian dari pemerintah. Untuk menyikapi hal tersebut, maka pembangunan pada sektor pertanian harus lebih ditingkatkan dengan cara mengetahui faktor-faktor penciri pembangunan sektor pertanian di Provinsi Bali. Salah satu analisis peubah ganda yang dapat mengetahui faktorfaktor penciri sektor pertanian di Provinsi Bali adalah analisis faktor. Dalam penelitian ini akan dilakukan analisis faktor untuk mendapatkan faktor-faktor

\footnotetext{
${ }^{1}$ Mahasiswa Jurusan Matematika FMIPA Universitas Udayana

${ }^{2,3}$ Staf Pengajar Jurusan Matematika FMIPA Universitas Udayana
} 
penciri dan mendapatkan peubah yang mewakili masing-masing faktor penciri tersebut.

Analisis peubah ganda merupakan suatu bagian analisis statistika yang menganalisis secara simultan peubah yang jumlahnya lebih dari dua dimana analisisnya dilakukan secara serempak. Analisis peubah ganda merupakan perluasan dari analisis univariat dan bivariat (Supranto, [5]).

Beberapa kegunaan penting dari analisis peubah ganda adalah (Siswadi, dan Suharjo, [4]): a) Penyederhanaan struktur. Upaya ini dilakukan untuk memperoleh cara-cara yang lebih mudah dalam mempresentasikan kompleksitas permasalahan yang dihadapi, b) Pengelompokan peubah, akan dilihat apakah peubah-peubah berada dalam satu kelompok atau tidak, c) Analisis kesalingtergantungan. Sasaran dari analisis ini adalah untuk memeriksa kesalingtergantungan peubah-peubah, d) Analisis ketergantungan. Dalam hal ini satu atau lebih peubah digunakan untuk memeriksa ketergantungannya terhadap peubah lain, e) Pembentukan dan pengujian hipotesis.

Analisis faktor merupakan salah satu teknik statistika multivariat berupa metode interdependensi yang digunakan untuk meringkas informasi yang ada dalam peubah awal menjadi satu set dimensi baru atau peubah ( factor). Hal ini dilakukan dengan cara menentukan struktur melalui data summarization atau data reduction (Hair et al , [2]).

Misalkan terdapat $p$ indikator dan $p$ faktor, maka dapat dibuat model sebagai berikut (Sharma, [3]) :

$X_{1}=\lambda_{11} F_{1}+\lambda_{12} F_{2}+\ldots+\lambda_{1 p} F_{p}+\varepsilon_{1} ;$
$X_{2}=\lambda_{21} F_{1}+\lambda_{22} F_{2}+\ldots+\lambda_{2 p} F_{p}+\varepsilon_{2} ;$ $\vdots$

$X_{p}=\lambda_{p 1} F_{1}+\lambda_{p 2} F_{2}+\ldots+\lambda_{p p} F_{p}+\varepsilon_{P}$

dengan $X_{1}, X_{2}, \ldots, X_{P}$ adalah indikator dari $p$ faktor, $\lambda_{11}, \lambda_{12}, \ldots, \lambda_{p p}$ adalah muatan (pembobot) peubah ke-1 sampai ke- $p$ pada faktor ke-1 sampai $p$, $F_{1}, F_{2}, \ldots, F_{P}$ menyatakan faktor ke-1 sampai ke- $p$ dan $\varepsilon_{1}, \varepsilon_{2}, \ldots, \varepsilon_{P}$ faktor unik untuk peubah ke-1 sampai ke- $p$.

Salah satu solusi dalam analisis faktor adalah dengan menggunakan pendekatan Analisis Komponen Utama (AKU). Misal dari pengamatan $p$ peubah dan $n$ objek, dapat ditulis dalam bentuk matriks berikut:

$$
X_{n \times p}=\left[\begin{array}{cccc}
x_{11} & x_{12} & \cdots & x_{1 p} \\
x_{21} & x_{22} & \cdots & x_{2 p} \\
\vdots & \vdots & \vdots & \vdots \\
x_{n 1} & x_{n 2} & \cdots & x_{n p}
\end{array}\right], \quad \Sigma_{p \times p}=\left[\begin{array}{cccc}
\Sigma_{11} & \Sigma_{12} & \cdots & \Sigma_{1 p} \\
\Sigma_{21} & \Sigma_{22} & \cdots & \Sigma_{2 p} \\
\vdots & \vdots & \vdots & \vdots \\
\Sigma_{p 1} & \Sigma_{p 2} & \cdots & \Sigma_{p p}
\end{array}\right]
$$


dengan $\mathrm{E}(\mathrm{X})=\mu$, matriks ragam $\Sigma$, dan komponen utamanya

$F_{i}, i=1,2, \ldots, p$.

$F_{1}=c_{11} X_{1}+c_{12} X_{2}+\ldots+c_{1 p} X_{p}=c_{1}^{\prime} X$

$F_{2}=c_{21} X_{1}+c_{22} X_{2}+\ldots+c_{2 p} X_{p}=c_{2}^{\prime} X$

:

$F_{p}=c_{p 1} X_{1}+c_{p 2} X_{2}+\ldots+c_{p p} X_{p}=c_{p}^{\prime} X$.

Bentuk persamaan dapat dituliskan

$F_{p \times l}=C_{p \times p}^{\prime} X_{p \times l}$,

$\left[\begin{array}{c}F_{1} \\ F_{2} \\ \vdots \\ F_{1}\end{array}\right]=\left[\begin{array}{cccc}c_{11} & c_{12} & \cdots & c_{1 p} \\ c_{21} & a_{22} & \cdots & c_{2 p} \\ \vdots & \vdots & \vdots & \vdots \\ c_{p 1} & a_{p 2} & \cdots & c_{p p}\end{array}\right]\left[\begin{array}{c}x_{1} \\ x_{2} \\ \vdots \\ x_{p}\end{array}\right]$

Komponen utama $F_{1}=c_{1}^{\prime} X$ diharapkan memiliki keragaman yang maksimum, sehingga dimungkinkan untuk memilih muatan (weight) atau koefisien nilai komponen sehingga faktor yang pertama menjelaskan sebagian besar porsi seluruh varians atau menyerap sebagian besar varians seluruh peubah. Kemudian muatan yang kedua dapat dipilih, sehingga faktor yang kedua menyerap sebagian besar sisa varians, setelah diambil faktor pertama, dengan syarat bahwa faktor yang kedua tidak berkorelasi dengan faktor pertama. Prinsip yang sama dapat dipergunakan untuk memilih faktor selanjutnya. Jadi faktor bisa diperkirakan sehingga nilai faktor yang satu tidak berkorelasi dengan nilai faktor lainnya.

\section{Metode Penelitian}

Sumber data pada penelitian ini adalah data sekunder yang diperoleh dari Badan Pusat Statistik (BPS) mengenai indikator pertanian di Bali tahun 2011. Data yang digunakan dalam penelitian mencakup 57 kecamatan yang ada di Provinsi Bali yang berkaitan dengan sektor pertanian di Bali. berupa data kuantitatif dengan skala rasio yaitu Jumlah Penduduk $\left(\mathrm{X}_{1}\right)$, Luas Panen Padi Sawah $\left(\mathrm{X}_{2}\right)$, Luas Panen Ubi-ubian dan Palawija $\left(\mathrm{X}_{3}\right)$, Luas Panen Tanam Sayursayuran $\left(\mathrm{X}_{4}\right)$, Jumlah Produksi Buah-Buahan $\left(\mathrm{X}_{5}\right)$, Jumlah Populasi Ternak Besar $\left(\mathrm{X}_{6}\right)$, Jumlah Populasi Ternak Unggas $\left(\mathrm{X}_{7}\right)$, Luas Pertanian Tanah Sawah $\left(\mathrm{X}_{8}\right)$, Luas Pertanian Tanah Bukan Sawah $\left(\mathrm{X}_{9}\right)$, Jumlah Produksi Perikanan Laut $\left(\mathrm{X}_{10}\right)$, Jumlah Produksi Perikanan Darat $\left(\mathrm{X}_{11}\right)$, Jumlah Produksi Padi Sawah $\left(\mathrm{X}_{12}\right)$, Jumlah Produksi Hasil Perkebunan $\left(\mathrm{X}_{13}\right)$, Luas Wilayah Kecamatan $\left(\mathrm{X}_{14}\right)$, Luas Tanaman Perkebunan $\left(\mathrm{X}_{15}\right)$, Luas Tanam Ubi - Ubian dan Palawija $\left(\mathrm{X}_{16}\right)$, Jumlah Produksi Ubi - Ubian dan Palawija $\left(\mathrm{X}_{17}\right)$, Luas Tanam Padi Sawah $\left(\mathrm{X}_{18}\right)$. (BPS, [1]).

Langkah-langkah dalam penelitian ini adalah: (1) mempersiapkan data pada Microsoft Excel 2007 yang akan diolah dengan menggunakan software SPSS.20; 
(2) menganalisis data dengan menggunakan analisis faktor dengan metode analisis komponen utama; (3) memeriksa banyaknya faktor yang terbentuk dengan melihat nilai eigen yang lebih besar dari satu; (4) memeriksa peubah-peubah masuk ke faktor mana;(5) melakukan rotasi faktor dengan menggunakan rotasi varimax; (6) mendapatkan faktor penciri beserta peubahnya dan melakukan interpretasi faktor.

\section{Hasil dan Pembahasan}

Sebelum melakukan analisis faktor dilakukan terlebih dahulu uji kelayakan data dengan mengunakan uji KMO dan uji bartlett. Hasil uji KMO dan uji bartlett dapat dilihat pada Tabel 3.2.

Tabel 3.2 Hasil KMO and Bartlett's test

\begin{tabular}{|c|c|c|}
\hline Kaiser-Meyer-Olkin Measu & $\begin{array}{l}\text { pling Adequacy. } \\
\text { Approx. Chi-Square }\end{array}$ & $\begin{array}{l}602 \\
604,752\end{array}$ \\
\hline Bartlett's Test of Sphericity & Df & 153 \\
\hline & Sig. &, 000 \\
\hline
\end{tabular}

Nilai KMO and Bartlett's Test untuk korelasi antarpeubah yang diinginkan adalah $>$ 0,5. Signifikansi penelitian ini adalah 0,05. Dari Tabel 3.2 diperoleh nilai KMO sebesar 0,602 berarti data lebih dari cukup untuk analisis faktor.

Berdasarkan analisis dengan menggunakan analisis faktor, faktor yang terbentuk dengan melihat nilai eigen yang lebih besar dari satu didapatkan 7 faktor dengan total keragaman yang dapat dijelaskan sebesar 76,417\%. Faktor 1 merupakan faktor penciri yang paling dominan dengan total nilai eigen terbesar yaitu 4,564 atau $25,356 \%$.

Selanjutnya dilakukan rotasi faktor untuk mengetahui peubah-peubah masuk faktor mana dan melakukan interpretasi faktor, didapatkan hasil sebagai berikut : a) Faktor 1 dinamakan faktor pertanian lahan kering terdiri dari lima peubah yaitu luas tanam ubi-ubian dan palawija, jumlah produksi ubi-ubian dan palawija, jumlah populasi ternak besar, luas wilayah kecamatan, dan luas pertanian tanah bukan sawah. Faktor ini menerangkan varian terbesar dari faktor lain yaitu sebesar $25,356 \%$. Peubah yang memiliki muatan faktor terbesar adalah luas tanam ubiubian dan palawija yaitu sebesar 0,920 , b) Faktor 2 dinamakan faktor pertanian lahan basah terdiri dari tiga peubah yaitu luas tanam padi sawah, jumlah produksi padi sawah, dan luas pertanian tanah sawah. Faktor ini mampu menjelaskan varian sebesar $15,007 \%$. Peubah yang memiliki muatan faktor terbesar adalah luas tanam padi sawah yaitu sebesar 0,937, c) Faktor 3 dinamakan faktor perkebunan terdiri dari dua peubah yaitu jumlah produksi hasil perkebunan, dan luas tanaman perkebunan. Faktor ini mampu menjelaskan varian sebesar 9,645\%. Peubah yang memiliki muatan faktor terbesar adalah jumlah produksi hasil perkebunan yaitu sebesar 0,764, d) Faktor 4 dinamakan faktor holtikultura terdiri dari dua peubah 
yaitu jumlah produksi buah-buahan, dan luas tanam sayur-sayuran. Faktor ini mampu menjelaskan varian sebesar $8,075 \%$. Peubah yang memiliki muatan faktor terbesar adalah jumlah produksi buah-buahan yaitu sebesar 0,759, e) Faktor 5 dinamakan faktor luas panen padi sawah terdiri dari dua peubah yaitu luas panen padi sawah, dan jumlah penduduk. Faktor ini mampu menjelasan varian sebesar $6,517 \%$. Peubah yang memiliki muatan faktor terbesar adalah luas panen padi sawah yaitu sebesar 0,782 , f) Faktor 6 dinamakan faktor luas panen ubi-ubian dan palawija terdiri dari dua peubah yaitu luas panen ubi-ubian dan palawija, dan jumlah populasi ternak unggas. Faktor ini mampu menjelaskan varian sebesar 6,078\%. Peubah yang memiliki muatan faktor terbesar adalah luas panen ubiubian dan palawija yaitu sebesar 0,761, dan g) Faktor 7 dinamakan faktor perikanan terdiri dari dua peubah yaitu jumlah produksi perikanan laut, dan jumlah produksi perikanan darat. Faktor ini mampu menjelaskan varian sebesar $5,739 \%$. Peubah yang memiliki muatan faktor terbesar adalah jumlah produksi perikanan laut yaitu sebesar 0,792 .

\section{Kesimpulan}

Berdasarkan hasil analisis diperoleh kesimpulan bahwa:

1. Didapatkan tujuh faktor penciri pembangunan sektor pertanian di Bali yaitu faktor pertanian lahan kering, faktor pertanian lahan basah, faktor perkebunan, faktor holtikultura, faktor luas panen padi sawah, faktor luas panen ubi-ubian dan palawija dan faktor perikanan.

2. Faktor penciri yang paling dominan dalam pembangunan sektor pertanian di Provinsi Bali adalah faktor pertanian lahan kering dengan total initial nilai eigen terbesar yaitu 4,564 atau 25,356\%.

3. Peubah yang mewakili masing-masing faktor yaitu luas tanam ubi-ubian dan palawija dengan muatan faktor sebesar 0,920 mewakili faktor pertanian lahan kering, luas tanam padi sawah dengan muatan faktor sebesar 0,937 mewakili faktor pertanian lahan basah, jumlah produksi hasil perkebunan dengan muatan faktor sebesar 0,764 mewakili faktor perkebunan, jumlah produksi buah-buahan dengan muatan faktor sebesar 0,759 mewakili faktor holtikultura, luas panen padi sawah dengan muatan faktor sebesar 0,782 mewakili faktor luas panen padi sawah, luas panen ubi-ubian dan palawija dengan muatan faktor sebesar 0,761 mewakili faktor luas panen ubi-ubian dan palawija, jumlah produksi perikanan laut dengan muatan faktor sebesar 0792 mewakili faktor perikanan. 


\section{Daftar Pustaka}

[1] BPS.2012. Bali dalam Angka 2012. Bali.

[2] Hair, Joseph F., Rilph F. Anderson, Ronald L. Tahtam dan William C. Black. 2006. Multivariate Data Analysis. Sixth Edition. New Jersey : Prentice-Hall Inc.w

[3] Sharma, S.1996. Applied Multivariate Techniques.John Wiley and Sons, Inc. New York.

[4] Siswadi dan Budi Suharjo. 1998. Analisis Eksplorasi Data Peubah Ganda. IPB Press kampus IPB Taman Kencana Bogor. Bogor.

[5] Supranto, J. 2004. Analisis Multivariat (Arti dan Interpretasi). Rineka Cipta. Jakarta. 